\title{
Anestesia em Paciente com Síndrome de Rubinstein-Taybi. Relato de Caso *
}

\section{Anesthesia in Patient with Rubinstein-Taybi Syndrome. Case Report}

Carlos Rogério Degrandi Oliveira, TSA ${ }^{1}$; Luciana Elias ${ }^{2}$

\section{RESUMO}

Oliveira CRD, Elias L - Anestesia em Paciente com Síndrome de Rubinstein-Taybi. Relato de Caso

JUSTIFICATIVA E OBJETIVOS: A síndrome de Rubinstein-Taybi (SRT) é uma doença genética causada por uma mutação ou apagamento do cromossomo 16 , caracterizada por retardo físico e mental, anormalidades craniofaciais e hálux e polegares largos. Há pouca informação sobre esta síndrome na literatura anestésica. O objetivo deste relato foi apresentar a conduta anestésica em paciente submetido à cirurgia odontológica e discutir as características de interesse para a anestesia nesses pacientes.

RELATO DO CASO: Paciente do sexo masculino, 9 anos, 28 $\mathrm{kg}$, submetido à anestesia geral para extrações de dentes anormalmente posicionados. Apresentava as características típicas da SRT, retardo físico e mental, anormalidades craniofaciais e hálux e polegares largos. A anestesia foi induzida e mantida com sevoflurano, inicialmente sob máscara facial e após intubação nasotraqueal em ventilação assistida manual com sistema de Bain. Não houve intercorrências e a cirurgia foi realizada em regime ambulatorial.

CONCLUSÕES: A importância da avaliação pré-anestésica é enfatizada, devido às malformações, inclusive cardíacas, associadas a esta síndrome. Este paciente, em particular, não apresentava comprometimento cardíaco, presente em um terço dos casos. É recomendável preparação para possível dificuldade de manutenção das vias aéreas.

Unitermos: ANESTESIA, Pediátrica; DOENÇAS: síndrome de Rubinstein-Taybi

\section{SUMMARY}

Oliveira CRD, Elias L - Anesthesia in Patient with RubinsteinTaybi Syndrome. Case Report

BACKGROUND AND OBJECTIVES: Rubinstein-Taybi syndrome (RTS) is a genetic disease caused by mutation or deletion of chromosome 16, and characterized by growth and mental retardation, clubbing thumbs and toes and craniofacial abnormalities. There is little information about RTS in the anesthetic literature. This report aimed at describing the anesthetic management of a patient with Rubinstein-Taybi syndrome submitted to dentistry surgery and at discussing aspects of this syndrome that may be relevant to anesthesia.

CASE REPORT: Male patient, 9-year-old, $28 \mathrm{~kg}$, to be submitted to general anesthesia for extraction of abnormally positioned teeth. Patient presented with typical RTS characteristics (growth and mental retardation, clubbing thumbs and toes and craniofacial abnormalities). Anesthesia was induced and initially maintained with sevoflurane under facial mask; after tracheal intubation it was maintained under manually controlled ventilation with Bain system. There have been no complications and procedure was performed in outpatient regimen.

CONCLUSIONS: The importance of thorough preanesthetic evaluation is emphasized due to possible associated malformations, including heart diseases. In this particular case, there was no heart disease, which is reported to be present in one-third of cases. Attention to difficult airway maintenance is recommended.

Key Words: ANESTHESIA, Pediatric; DISEASES: Rubinstein-Taybi syndrome

\section{INTRODUÇÃO}

A síndrome de Rubinstein-Taybi (SRT) é uma doença geAnética causada por anomalia do cromossomo 16. Os portadores apresentam retardo físico e mental, anormalidades craniofaciais e hálux e polegares largos. Um terço dos pacientes apresentam cardiopatias congênitas. Na literatura, há pouca informação sobre a conduta anestésica nessa síndrome, no entanto muitos pacientes com SRT precisam ser submetidos à anestesia, para investigação diagnóstica ou correção cirúrgica das múltiplas malformações.

O objetivo deste relato foi apresentar a conduta anestésica em um paciente submetido à cirurgia odontológica para extração de dentes anormalmente posicionados e discutir as características que possam ser de interesse para a anestesia.

\section{RELATO DO CASO}

Paciente do sexo masculino, 9 anos, $28 \mathrm{~kg}$, com diagnóstico de SRT desde o nascimento, foi agendado para cirurgia odontológica para extrair dentes anormalmente posiciona- 
dos. Apesar do caráter amigável deste paciente, não foi possível a realização do procedimento no consultório, com anestesia local, por falta de cooperação, isto fez com que fosse encaminhado ao serviço de Anestesiologia para avaliação e realização do procedimento sob anestesia geral. Acriança não fazia uso de medicamentos de rotina. Apresentava antecedentes de asma brônquica até os quatro anos, e internações por broncopneumonia e para adenoamigdalectomia. Ao exame físico, apresentava Mallampati classe III, fácies típica com microcefalia, hipertelorismo, maxila hipoplásica e retrognatia (Figura 1). Aavaliação cardiológica que constou de exame clínico, eletrocardiograma e ecocardiograma, não evidenciou doenças ou malformações.

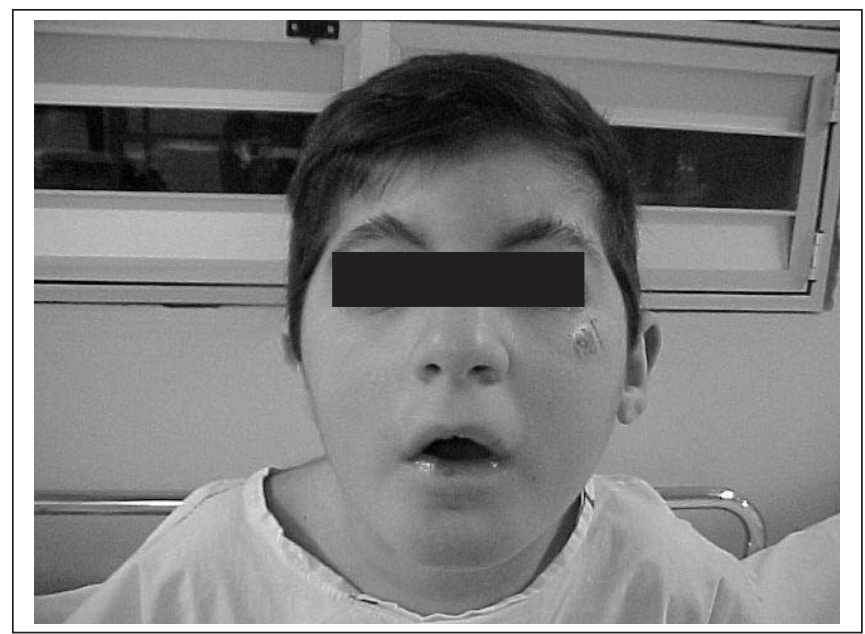

Figura 1 - Fácies Característica da Síndrome de Rubinstein-Taybi

Não foi utilizada medicação pré-anestésica. O material para controle de via aérea difícil foi preparado (estiletes, máscara laríngea e laringofibroscópio).

Após monitorização com estetoscópio precordial, pressão arterial não-invasiva, cardioscópio e oximetro de pulso, foi feita indução inalatória sob máscara facial com sevoflurano e $\mathrm{O}_{2}$ com auxilio do sistema de Bain. Após a indução, foi feita venóclise com cateter $22 \mathrm{G}$ no membro superior direito.

Foi realizada laringoscopia prévia com lâmina curva e atribuído Cormak-Lehane II, a seguir foi feita intubação por via nasal, com auxílio de uma pinça de Magill, com tubo traqueal $5,5 \mathrm{~mm}$ com balonete. A manutenção da anestesia foi realizada com $\mathrm{O}_{2} / \mathrm{N}_{2} \mathrm{O}(33 \% / 66 \%)$ e sevoflurano em concentrações variáveis ( $3 \%$ a $4,5 \%$ ) e a ventilação foi mantida espontânea, com assistência por pressão positiva manual, apenas no início do procedimento.

Foi realizado bloqueio infiltrativo com levobupivacaína a $0,25 \%$ com vasoconstritor pelo cirurgião.

$\mathrm{O}$ ato anestésico-cirúrgico durou 60 minutos, tempo em que o paciente apresentou estabilidade hemodinâmica; sendo extubado após aspiração das vias aéreas e presença dos reflexos protetores. Após quatro horas de permanência na

Revista Brasileira de Anestesiologia

Vol. 55, № 5, Setembro - Outubro, 2005
SRPA, preencheu todos os critérios para alta em regime ambulatorial.

\section{DISCUSSÃO}

Em 1963 dois médicos, Jack H. Rubinstein e Hooshang Taybi, fizeram um relato de sete crianças com polegares e hálux largos e grandes, associados com anomalias craniofaciais e retardo mental ${ }^{1}$. Mais tarde outras características foram relatadas, entre elas, infecções respiratórias de repetição e cardiopatia congênita em um terço dos casos ${ }^{2}$.

Estas alterações são ocasionadas por um apagamento ou mutação do cromossomo $16^{3,4}$. A SRT é encontrada uniformemente na população masculina e feminina. A síndrome era tida como rara, mas tem havido um aumento no número de casos informados de SRT a cada ano, fazendo com que não seja tão rara quanto foi imaginada inicialmente. Estima-se que seja de um para cada 600 pacientes em clínicas para doenças mentais ${ }^{5}$. É muito comum que uma criança ligeiramente afetada, não apresente nenhum problema médico grave, características extremas ou retardo mental significativo, tenha o diagnóstico feito apenas na adolescência. Há dois relatos na literatura de gêmeos monozigóticos ${ }^{6,7}$, assim como um relato de mãe e filho portadores da SRT ${ }^{8}$.

O diagnóstico geralmente é feito no período neonatal pela presença das anormalidades típicas; no entanto, a associação com outras síndromes ou doenças tem sido relatada, o que pode tornar o diagnóstico mais difícil, exigindo, nestes casos, uma avaliação genética ${ }^{\text {9-11. }}$.

Os pacientes apresentam uma boa expectativa de vida, sendo freqüente os relatos de adultos com SRT. As infecções respiratórias e as complicações decorrentes das malformações cardíacas na infância são as principais causas de morbidade e mortalidade nesta síndrome ${ }^{12}$.

Os problemas durante o manuseio anestésico dessas crianças estão centrados em duas áreas principais, anomalias esqueléticas (craniofaciais e vertebrais) e alterações cardiovasculares.

A expressão fenotípica é variável, sendo que as anomalias craniofaciais podem incluir microcefalia, fendas palpebrais antimongoloídes, nariz pontiagudo, hipertelorismo, mandíbula hipoplásica, palato arqueado, retrognatia e micrognatia ${ }^{13,14}$.

Algumas destas malformações anatômicas podem resultar em estreitamento e colapso das vias aéreas superiores, que tem sido referido como causa de problemas de ventilação em indivíduos não anestesiados ${ }^{13-15}$.

Alterações dentárias que ocorrem com freqüência, que levam estes pacientes a procedimentos sob anestesia geral para realizar restaurações, exodontias múltiplas e avaliações ortognáticas ${ }^{16-18}$.

Outras alterações são observadas como a hipercifose cervical, presente em $62 \%$, e a escoliose em $38 \%$ em um estudo de 45 pacientes com SRT ${ }^{16}$.

O procedimento anestésico pode também ser diretamente afetado pelas anomalias cardíacas que trazem riscos substanciais a este grupo de pacientes. Apesar de não haver ne- 
nhum defeito cardíaco específico para a síndrome, eles ocorrem em cerca de $33 \%$ dos pacientes, exigindo, muitas vezes, correção precoce ${ }^{19-21}$. As malformações mais freqüentes são a CIA, a CIV, a persistência do ducto arterioso, a coarctação da aorta, a estenose pulmonar e a valva aórtica bicúspide ${ }^{19}$. A presença de anormalidades estruturais e funcionais cardíacas aumenta a incidência de disritmias, principalmente quando são usadas drogas vasoativas. Aalteração do tônus simpático e parassimpático pela neostigmina e atropina poderá desencadear ritmos ectópicos ${ }^{22}$. A succinilcolina deve ser evitada nestes pacientes, pois é responsabilizada pelo aparecimento de taquicardia supraventricular, contrações atriais e ventriculares prematuras ${ }^{22}$.

O mecanismo freqüente de comprometimento respiratório inclui aspiração do conteúdo gástrico, principalmente durante o sono e o despertar. A aspiração recorrente é freqüentemente associada com pneumonia crônica ou aguda ${ }^{2}$.

O uso de medicação pré-anestésica deve ser prudente. Medicações sedativas podem ser eficientes para diminuir a tensão psicológica, mas o risco de depressão respiratória e comprometimento das vias aéreas superiores podem desaconselhar sua prescrição.

Alterações oftalmológicas podem estar presentes, entre elas, o glaucoma congênito ${ }^{23-26}$. É relatada a associação com hipotireoidismo congênito ${ }^{27,28}$.

Os pacientes portadores desta síndrome apresentam maior incidência de neoplasias malignas e benignas, principalmente da cabeça e do pescoço ${ }^{29-32}$.

Bloqueios no neuro-eixo podem ser utilizados, desde que os pacientes não apresentem alterações da coluna vertebral. Há um relato de anestesia geral complementada com bloqueio sacral para herniorrafia inguinal bilateral ${ }^{33}$.

Devido às alterações metacarpofalangianas dos polegares timulação do nervo ulnar e a observação do músculo adutor do polegar por aceleromiografia deve ser evitada, dando-se preferência para a estimulação do nervo facial e a observação do músculo orbicular do olho.

Pela grande variedade de fenótipos que a SRT pode apresentar, deve-se estar preparado para o manuseio da via aérea difícil. Embora estes pacientes apresentem via aérea difícil reconhecida, em muitos casos não há dificuldade de intubação, demonstrando que nem sempre há correlação entre os critérios de previsibilidade de intubação difícil e sua ocorrência ${ }^{35-37}$.

A máscara laríngea mostrou-se útil no controle da via aérea em paciente adulto com SRT submetido à cirurgia oftalmológica $^{38}$.

Como a SRT apresenta uma significantiva incidência de comprometimento cardiológico, uma avaliação pré-operatória cuidadosa é recomendada em todos os pacientes a serem submetidos a procedimento anestésico para determinação adequada da condição clínica e dos riscos associados $^{19}$.

No caso relatado o paciente não apresentava cardiopatia e devido à história de exposição prévia à anestesia geral inalatória, optou-se por repetir esta técnica. A opção pelo sevoflu${ }^{34}$, a monitorização do relaxamento muscular que utilize a es-

rano, como agente inalatório, baseou-se nas suas propriedades favoráveis para anestesia pediátrica.

Pela condição clínica do paciente e transcurso da anestesia, foi possível atendê-lo em regime ambulatorial.

\section{Anesthesia in Patient with Rubinstein- Taybi Syndrome. Case Report} Carlos Rogério Degrandi Oliveira, TSA, M.D.; Luciana Elias,
M.D.

\section{INTRODUCTION}

Rubinstein-Taybi syndrome (RTS) is a genetic disease caused by chromosome 16 abnormalities and leading to physical and mental retardation, craniofacial abnormalities and clubbing thumbs and toes. One third of patients also present congenital heart diseases. There is little information in the literature about the anesthetic approach for this syndrome, however several RTS patients have to be submitted to anesthesia for diagnostic investigation or surgical correction of multiple malformations.

This report aimed at describing the anesthetic management of a patient with Rubinstein-Taybi syndrome submitted to dentistry surgery for extraction of abnormally positioned teeth, and at discussing aspects of this syndrome that may be relevant to anesthesia.

\section{CASE REPORT}

Male patient, 9 years old, $28 \mathrm{~kg}$, with diagnosis of RTS since birth, was scheduled for dentistry surgery for extraction abnormally positioned teeth. Notwithstanding the friendly mood of this patient, procedure could not be performed at the dentist office under local anesthesia due to lack of cooperation. Patient was then referred to the Anesthesiology department for evaluation and performing of the procedure under general anesthesia.

Patient was not routinely medicated. Patient presented history of bronchial asthma until 4 years of age and of hospital admissions due to bronchopneumonia and adenotonsillectomy. At physical evaluation, patient presented Mallampati class III, typical face with microcephaly, hypertelorism, hypoplastic maxilla and retrognathism (Figure 1). Cardiologic evaluation by clinical exam, ECG and EEG has not revealed diseases or malformations.

Patient was not premedicated. Material to difficult airway management was prepared (stilets, laryngeal mask and laryngofibroscope).

After monitoring with precordial stethoscope, noninvasive blood pressure, cardioscopy and pulse oximetry, inhalational anesthesia was induced under facial mask with sevoflurane and $\mathrm{O}_{2}$ by Bain system. Right arm was catheterized with $22 \mathrm{G}$ catheter after anesthetic induction. 


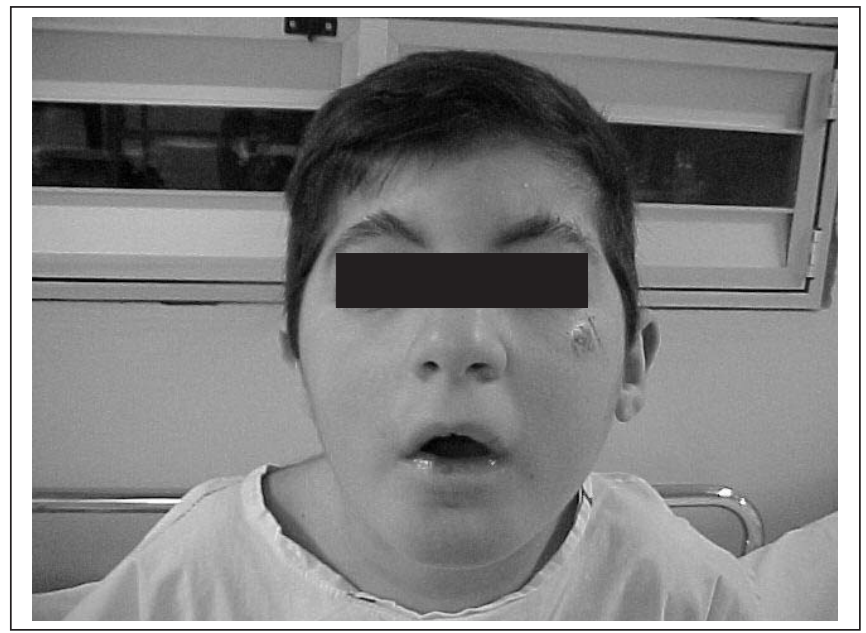

Figure 1 - Typical Face of Rubinstein-Taybi Syndrome

Previous laryngoscopy with curve blade was performed and Cormak-Lehane II was attributed. Then patient was nasally intubated with the aid of Magill's clamp, with 5.5 cuffed tracheal tube. Anesthesia was maintained with $\mathrm{O}_{2}, \mathrm{~N}_{2} \mathrm{O}$ $(33 \% / 66 \%)$ and sevoflurane in variable concentrations $(3 \%$ to $4.5 \%$ ), spontaneous ventilation was maintained and complemented by manual ventilation only in the beginning of the procedure.

Infiltrative block was performed by the surgeon with $0.25 \%$ levobupivacaine with vasoconstrictor. Procedure lasted 60 minutes with patient hemodynamically stable. Patient was extubated after airway aspiration and presence of protecting reflexes. Patient was discharged 4 hours after being referred to PACU.

\section{DISCUSSION}

In 1963, two physicians, Jack H. Rubinstein and Hooshang Taybi, have reported the case of seven children with clubbing and large thumbs and toes, associated to craniofacial abnormalities and mental retardation ${ }^{1}$. Later, other characteristics were reported, such as repetition respiratory infections and congenital heart disease in one third of cases ${ }^{2}$.

These changes are caused by mutation or deletion of chromosome $16^{3,4}$. RTS is uniformly distributed between males and females. Syndrome was considered uncommon, but there has been increased number of cases reported every year, making it not so uncommon as it was initially thought. It is estimated that $1: 600$ patients admitted to mental clinics present this disease ${ }^{5}$. It is very common that a child mildly affected does not show any severe medical problem, extreme characteristics or significant mental retardation being diagnosed only during adolescence. There are two reports in the literature of monozygotic twins ${ }^{6,7}$, as well as a report on mother and child with RTS ${ }^{8}$.

Diagnosis is in general done in the neonatal period by the presence of typical abnormalities, however the association

Revista Brasileira de Anestesiologia

Vol. 55, № 5, Setembro - Outubro, 2005 with other syndromes or diseases has been reported, which may make more difficult the diagnosis and require genetic evaluation ${ }^{9-11}$

Patients have good life expectancy and reports on adults with STR are frequent. Respiratory infections and complications caused by heart malformations during childhood are major causes of morbidity and mortality ${ }^{12}$.

Problems during anesthetic management of these children are focused on two major areas: skeletal abnormalities (craniofacial and vertebral) and cardiovascular changes. Phenotypic expression is variable, and craniofacial abnormalities may include: microcephaly, eyelid antimongoloid clefts, sharp nose, hypertelorism, hypoplastic mandible, arched palate, retrognathism and micrognathism ${ }^{13,14}$.

Some anatomic malformation may result in narrowing and collapsing of upper airways, and this has been reported as cause of ventilation problems in non-anesthetized individuals ${ }^{13-15}$

Dental abnormalities are frequent and lead these patients to procedures under general anesthesia for restorations, multiple extractions and orthognathic evaluations ${ }^{16-18}$.

Cervical hyperkyphosis was present in $62 \%$ and scoliosis in $38 \%$ of patients in a study with 45 RTS patients ${ }^{16}$.

The anesthetic procedure may also be directly affected by cardiac abnormalities, which bring major risks for this group of patients. Although there is no syndrome-specific defect, they are present in approximately $33 \%$ of patients, very often requiring early correction ${ }^{19-21}$. Most frequent malformations are CIA, CIV, ductus arteriosus persistence, aortic coarctation, lung stenosis and bicuspid aortic valve ${ }^{19}$. The presence of cardiac structural and functional abnormalities increases the incidence of arrhythmias, especially when vasoactive drugs are used. Neostigmine and atropine-induced changes in sympathetic and parasympathetic tone may trigger ectopic rhythms ${ }^{22}$. Succinylcholine should be avoided in these patients because it is responsible for supraventricular tachycardia, and early atrial and ventricular contractions ${ }^{22}$. Most frequent respiratory complication is gastric content aspiration, especially during sleep and emergence. Recurrent aspiration is frequently associated to chronic or acute pneumonia ${ }^{2}$.

Premedication should be carefully given. Sedatives may be effective to decrease psychological stress, but the risk of respiratory depression and upper airway problems may make them undesirable.

Eye changes may be present, among them congenital glaucoma ${ }^{23-26}$. The association with congenital hyperthyroidism is also reported ${ }^{27,28}$.

Patients with this syndrome have a higher incidence of malignant and benign neoplasias, especially of head and neck 29-32.

Neuraxial blocks may be used, provided patients have no spinal abnormalities. There is a report on general anesthesia complemented with sacral block for bilateral inguinal hernia correction $^{33}$.

Due to thumb metacarpophalangeal changes ${ }^{34}$, muscle relaxation monitoring with ulnar nerve stimulation and observa- 
tion of adductor pollicis muscle by acceleromyography should be avoided, giving preference to facial nerve stimulation and observation of orbicular muscle of eye.

Due to the wide variety of RTS phenotypes, one should be ready for handling difficult airways. Although these patients have recognized difficult airways, there are some cases of easy intubation, showing that there is not always correlation between previous predictability criteria and the presence of difficult intubation ${ }^{35-37}$.

Laryngeal mask has shown to be useful to control difficult airways in adult RTS patient submitted to eye surgery ${ }^{38}$.

Since RTS courses with a significant incidence of heart involvement, a careful preoperative evaluation is recommended for all patients to be submitted to anesthetic procedures to determine adequate clinical conditions and associated risks ${ }^{19}$.

Our patient had no heart disease and due to the history of previous exposure to inhalational anesthesia we decided to repeat this technique. Sevoflurane was the inhalational agent of choice because of its favorable properties for pediatric anesthesia.

Patient's clinical condition and anesthetic outcome have allowed operating him in outpatient regimen.

\section{REFERÊNCIAS - REFERENCES}

01. Rubinstein $\mathrm{JH}$, Taybi $\mathrm{H}$ - Broad thumbs and toes and facial abnormalities. A possible mental retardation syndrome. Am J Dis Child, 1963;105:588-608.

02. Isayama S, Nakayama R, Sakamoto M et al - General anesthesia for an infant with Rubinstein-Taybi syndrome. Masui, 1997;46:1094-1096.

03. Petrij F, Dauwerse HG, Blough RI et al - Diagnostic analysis of the Rubinstein-Taybi syndrome: five cosmids should be used for microdeletion detection and low number of protein truncating mutations. J Med Genet, 2000;37:168-176.

04. Lacombe D - Rubinstein-Taybi syndrome. Arch Pediatr, 1994;1:681-683.

05. Cantani A, Gagliesi D - Rubinstein-Taybi syndrome. Review of 732 cases and analysis of the typical traits. Eur Rev Med Pharmacol Sci, 1998;2:81-87.

06. Preis S, Majewski F - Monozygotic twins concordant for Rubinstein-Taybi syndrome: changing phenotype during infancy. Clin Genet, 1995;48:72-75.

07. Ghanem Q, Dawod S - Monozygotic twins concordant for Rubinstein-Taybi syndrome. Clin Genet, 1990;37:429-434.

08. Hennekam RC, Lommen EJ, Strengers JL et al - RubinsteinTaybi syndrome in a mother and son. Eur J Pediatr, 1989;148: 439-441.

09. Cruz OA, Mason DM, Eswara MS et al - Duane retraction syndrome associated with Rubinstein-Taybi syndrome. Ophthalmic Genet, 1995;16:171-175.

10. Bonioli E, Bellini C, Di Stefano A - Unusual association: Dandy-Walker-like malformation in the Rubinstein-Taybi syndrome. Am J Med Genet, 1989;33:420-421.

11. Kim CJ, Nam JH, Chung $\mathrm{HY}$ et al - Kimura disease in a patient with Rubinstein-Taybi syndrome. Pediatr Int, 2004;46:609-611.

12. Rubinstein, JH - Broad thumb-hallux (Rubinstein-Taybi) syndrome 1957-1988. Am J Med Genet, 1990;6:(Suppl):3-16.
13. Hennekam RC, Van Doorne JM - Oral aspects of Rubinstein-Taybi syndrome. Am J Med Genet, 1990;6: (Suppl):42-47.

14. Baxter G, Beer J - Rubinstein-Taybi syndrome. Psychol Rep, 1992;70:451-456.

15. Zucconi M, Ferini-Strambi L, Erminio C et al - Obstructive sleep apnea in the Rubinstein-Taybi syndrome. Respiration, 1993;60:127-132.

16. Hennekam RC - Bibliography on Rubinstein-Taybi syndrome. Am J Med Genet, 1990;6:(Suppl):77-83.

17. Tokarz A, Gaszynski T, Gaszynski W et al - General anaesthesia for a child with Rubinstein-Taybi syndrome. Eur J Anaesthesiol, 2002;19:896-897.

18. Papagrigorakis MJ, Daliouris CP, Spyropoulos ND - Three cases of Rubinstein-Taybi syndrome. Odontostomatol Proodos, 1989;43:451-458.

19. Stevens CA, Bhakta MG - Cardiac abnormalities in the Rubinstein-Taybi syndrome. Am J Med Genet, 1995;59: 346-348.

20. Hanauer D, Argilla M, Wallerstein R - Rubinstein-Taybi syndrome and hypoplastic left heart. Am J Med Genet, 2002;112:109-111.

21. Maurer I, Regensburger D, Bernhard A- Aortic valve reconstruction in Rubinstein-Taybi-syndrome: the valuable aid of transesophageal echocardiography. J Cardiovasc Surg, 1991;32:327-329.

22. Stirt JÁ - Anesthetic problems in Rubinstein-Taybi syndrome. Anesth Analg, 1981;60:534-536.

23. Quaranta L, Quaranta CA - Congenital glaucoma associated with Rubinstein-Taybi syndrome. Acta Ophthalmol Scand, 1998;76:112-113.

24. Bogdanici C, Neamtu N, Rusu C - Ocular signs in Rubinstein-Taybi's syndrome. Oftalmologia, 2001;53:26-30.

25. Fujisawa K, Kinoshita K, Tawara A et al - A case of Rubinstein-Taybi syndrome suspected with goniodysgenetic glaucoma. Nippon Ganka Gakkai Zasshi, 1990;94:693-700.

26. van Genderen MM, Kinds GF, Riemslag FC et al - Ocular features in Rubinstein-Taybi syndrome: investigation of 24 patients and review of the literature. $\mathrm{Br} \mathrm{J}$ Ophthalmol, 2000;84: $1177-1184$

27. Kurtoglu S, Akcakus M, Gunes T et al - Congenital hypothyroidism associated with Rubinstein-Taybi syndrome. J Pediatr Endocrinol Metab, 2003;16:457-459.

28. Olson DP, Koenig RJ - Thyroid function in Rubinstein-Taybi syndrome. J Clin Endocrinol Metab, 1997;82:3264-3266.

29. Masuno M, Imaizumi $K$, Ishii $T$ et al - Pilomatrixomas in Rubinstein-Taybi syndrome. Am J Med Genet, 1998;77:81-82.

30. Skousen GJ, Wardinsky T, Chenaille P - Medulloblastoma in patient with Rubinstein-Taybi syndrome. Am J Med Genet, 1996;66:367.

31. Miller RW, Rubinstein JH - Tumors in Rubinstein-Taybi syndrome. Am J Med Genet, 1995;56:112-115.

32. Siraganian PA, Rubinstein JH, Miller RW - Keloids and neoplasms in the Rubinstein-Taybi syndrome. Med Pediatr Oncol, 1989;17:485-491.

33. Critchley LA, Gin T, Stuart JC - Anaesthesia in an infant with Rubinstein-Taybi syndrome. Anaesthesia, 1995;50:37-38.

34. Hennekam RC, Van Den Boogaard MJ, Dijkstra P et al Metacarpophalangeal pattern profile analysis in Rubinstein-Taybi syndrome. Am J Med Genet, 1990;6:(Suppl): 48-50.

35. Azevedo VLF, Santos PSS - Anestesia em paciente com Síndrome de Rubinstein-Taybi.Relato de Caso. Rev Bras Anestesiol, 2004;54:(Suppl33):CBA270B. 
36. Altintas F, Cakmakkaya S - Anesthetic management of a child with Rubinstein-Taybi syndrome. Paediatr Anaesth, 2004;14: 610-611.

37. Oliveira CRD, Elias $L$ - Anestesia em paciente com Síndrome de Rubinstein-Taybi.Relato de Caso. Rev Bras Anestesiol, 2004;54(Suppl33):CBA288A.

38. Twigg SJ, Cook TM - Anaesthesia in an adult with Rubenstein-Taybi syndrome using the ProSeal laryngeal mask airway. Br J Anaesth, 2002;89:786-787.

\section{RESUMEN}

Oliveira CRD, Elias L - Anestesia en Paciente con Síndrome de Rubinstein-Taybi. Relato de Caso

JUSTIFICATIVA Y OBJETIVOS: El sindrome de Rubinstein-Taybi (SRT) es una enfermedad genética causada por una mutación o apagamiento del cromosoma 16 , caracterizada por retardo físico y mental, anormalidades craneofaciales y hálux y pulgares anchos. Hay poca información sobre este síndrome en la literatura anestésica. El objetivo de este relato ha sido en presentar la conducta anestésica en paciente sometido a cirugía odontológica y discutir las características de interés para la anestesia en estos pacientes.

RELATO DEL CASO: Paciente del sexo masculino, 9 años, 28 $\mathrm{kg}$, sometido a la anestesia general para extracciones de dientes anormalmente posicionados. Presentaba las características típicas de la SRT, retardo físico y mental, anormalidades craneofaciales y hálux y pulgares anchos. La anestesia fue inducida y mantenida con sevoflurano, inicialmente bajo máscara facial y después intubación nasotraqueal en ventilación asistida manual con sistema de Bain. No hubo interocurrencias y la cirugía fue realizada en régimen ambulatorial.

CONCLUSIONES: La importancia de la evaluación pre-anestésica es realizada, debido a las malformaciones, incluso cardíacas, asociadas a este síndrome. En este caso en particular, el paciente no presentaba comprometimiento cardíaco, presente en un tercio de los casos. Se recomienda preparación para una posible dificultad de mantenimiento de las vías aéreas. 